\title{
Muslim Occupation in France According to Arabic Literature and Western Historical Evidences
}

\author{
Meirison, ${ }^{*}$ Zaim Rais, ${ }^{* *}$ Husnul Fatarib ${ }^{* * *} \&$ Qasem Muhammadi***
}

\begin{abstract}
Islam has a long history in Southern France and Italy and has contributed greatly to the formation of European civilization. This has been forgotten mainly by European and French people and Muslims in general. Driven by the Spirit of jihad and the spread of Islam, the Muslim soldiers have made France and Italy's regions into an orderly administrative region that was previously filled up with injustice. A comparison of Arabic and Western literature, especially French and Spanish and Arabic literature, was conducted to complete this discussion. Arabic literature does not indicate in detail that Muslims have been in France for a long time based on physical evidence obtained in modern times. By conducting a literature study and a comparative historical, descriptive approach, it was found that Muslims suffered a crushing defeat in the battle with Charles Martel in Tours, October 10, 732. However, Muslims were still in Gaul, Bordeaux, and Anjou (Italy), and it took place for 250 years. This shows that Muslims could adapt to the local population. Coupled with research carried out by archaeologists, gynaecologists, and sociologists with Muslim graves' presence in the Gaul region joined by local residents, Barbarians, and Arabs indicated that the procedure for burial was performed according to Islam. The funerals were carried out in the 7th or 9th century A.D. The history of Muslims in France and Italy is not easily forgotten; these experts' research has perpetuated Muslims' narrative in France and Italy.
\end{abstract}

Keywords: Muslims, occupation, literature, history

\section{Introduction}

This discussion is not directly related to Malay in Indonesia, but the relationship between the Umayyads and Indonesia had been going on for a long time. The Umayyads had developed their influence in spreading Islam to Jambi. Sri Indrawarman (702-728 A.D) once sent a letter to Umar bin Abdul Aziz (717-720 A.D) to send scholars to teach Islamic shari'ah implemented in the territory of the Srivijaya kingdom. ${ }^{1}$

Muslim Arabs conquered Andalusia and formed a government with a vast territory covering the entire Iberian peninsula. The Muslim army entering French territory at that time was led by as-Samh bin Malik al-Khaulani. He conquered the region of Septimania, the region which borders Narbo and Toulouse. ${ }^{2}$ However, the Duke of Occitan, named Odo (Duke Odo), did not want to give up. When the Muslims besieged the city of Toulouse for a long time, its inhabitants almost gave up. ${ }^{3}$ However, as-Samh died in the battle. After several changes of leaders, Abdurahman al-Ghafiqi, a Tabi'in who still had time to frequent some of the Prophet's companions, was appointed the leader. The social and political situation got better when Abdul Rahman Al-Ghafiqi was appointed to lead Andalusia. ${ }^{4} \mathrm{He}$ was respected by the people he led for his excellence and fair leadership. In distributing war reparations, he prioritized the interests of his troops over his own. He was also a pious leader and was known as one of the companions of Ibn Umar R.A, one of the Companions of the Prophet PBUH.

\footnotetext{
* Meirison (Ph.D), Senior Lecturer, Faculty of Ushuluddin, Universitas Islam Negeri (UIN) Imam Bonjol Padang, Indonesia. Email: meirison@uinib.ac.id.

${ }^{* *}$ Zaim Rais (Ph.D), Associate Professor, Faculty of Ushuluddin, Universitas Islam Negeri (UIN) Imam Bonjol Padang, Indonesia. Email: zaimrais@uinib.ac.id.

Husnul Fatarib (Ph.D), Associate Professor, Fakultas Ushuluddin IAIN Metro, Lampung, Indonesia. Email: husnulfatarib@metrouniv.ac.id.

${ }^{* * * *}$ Qasem Muhammadi, President of International Cultural Center of Rahmatan lil Alamin, 22 ${ }^{\text {nd }}$ Bahonar, Karimi blvd, Qom, Iran.

${ }^{1}$ Wandiyo Wandiyo, Ida Suryani and Kabib Sholeh (2020), "Hubungan Sriwijaya dengan Dinasti Umayah terhadap Masuknya Agama Islam di Palembang pada Abad VIII Masehi," SINDANG: Jurnal Pendidikan Sejarah dan Kajian Sejarah, Vol. 2, No. 1, $32-43$.

${ }^{2}$ Toulouse (Tolosa in Occitan language) is a city in southwestern France on the banks of the Garonne River, in the middle of the distance between the Atlantic Ocean and the Mediterranean Sea.

${ }^{3}$ Muḥammad Suhayl Ṭaqūush (2005), Tārīkh Al-Muslimīn F̄̄al-Andalus, 91-897 H/710-1492 M, al-Ṭab'ah 1. Bayrūt: Dār al-Nafā'is, p. 22.

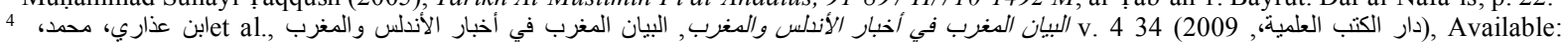
https://books.google.co.id/books?id=u5bTzAEACAAJ.
} 
Al-Ghafiqi was a formidable leader and administrator, an enthusiastic reformer, a person of kindness with ideal qualities, and a strong sense of justice, patience, and religiosity. The previous governors were in charge for not more than three years. Finally, the reins of leadership fell to Abdurrahman Al-Ghafiqi in 730 A.D. Abdurrahman began to fix the situation in Andalusia by quelling the rebellion between Arabs and Barbarians. At that time, Duke Odo (679-688 AD) was Duke Aquitaine and had made a peace treaty with Catalonia's Muslim governor. Odo believed that his real enemy was Charles Martel, who controlled the castles and fortresses in Paris, which was France's absolute ruler. By making peace with Muslims, he would be safe and could face Charles Martel. Usman bin Naisa al-Barbari has committed treason, this deputy governor of Catalonia, allied with Odo Duke Aquitaine. ${ }^{5} \mathrm{He}$ could still be used, or at least the execution of Usman bin Naisa al-Barbari was postponed due to precarious circumstances and could save many soldiers' lives before moving to the North. The Muslims were defeated in a war that determined the fate of expansion, and the Islamic da'wah was getting ready to go to the heart of Europe. The battlefield was called Balath as-Syuhada, which was the way to the shrine since Roman times where the two sides fought each other, and the word Syuhada was added because many Muslims died in the battle.

Meanwhile, the Europeans called it the Battle of Tours and Poitiers as it was close to the two cities. ${ }^{6}$ One of the expansion objectives was the expansion of the Umayyad territory to Byzantium through Eastern Europe because the previous rulers had not succeeded in conquering the Byzantine Empire from the East. So they tried to conquer this old empire from the West. That was the journey of Muslims' struggle in France and Italy to spread Islam's peaceful religion. ${ }^{7}$ France's territory was inhabited by pirates and thieves who disrupted security, which was sometimes managed by cardinals who were emissaries of the pope to control the sphere of territory. There was no country at that time, and it was the only duchy.

This history is rarely discussed by Muslim and non-Muslim historians, especially in the country where this incident took place, namely France, which tried to obscure the Muslims' history there. Meanwhile, Jewish and Christian history is discussed clearly and in detail. This research was a literature study using a descriptive analysis approach. We analyzed sources such as the Andalusian history book entitled "Tarikh Muslimin wa Atsaruhum fi al-Andalus", which analyses Muslims' defeat and explains the process of Muslim occupation in France and Italy as well as interactions with the people in Indonesia. France, especially in Bordeaux, has established good relations so that the people in that area have inherited how to make cheese and how to process and serve food ingredients. ${ }^{8}$ To prove the truth of the stories in the literature, we tried to find notes and research results published in the Journal of Pos One, which states that there were indeed Muslim soldiers in the 7th or 8th century in France from various ethnicities, both from North Africa, Arab and local residents who had converted to Islam. Many research like Archaeological, gynaecological, and sociological can prove that Muslims in France have managed government and trading activities for 250 years. We reinterpreted history by doing a literature study and descriptive and historical-comparative approach, which has not yet appeared clearly. Muslims have been living for an indefinitely long period in Sens, not far from Paris. The tradition has spread that those who teach the people around the Sens area are taught how to process cheese by the Arabs. ${ }^{9}$ The novelty of this present paper lies in its discussion of historical evidence that Muslims have been in France and Italy for a long time and have mingled with the local population by carrying out trade activities and government administration. ${ }^{10}$

\section{Discussion}

The Muslims did not leave France until the establishment of the Banu Umayah dynasty in Andalusia in 756. Abdurrahman ad-Dakhil decided to take back the Muslim troops from Gaul and limit the Umayyad Regions only to Andalusia. Whereas previously Musa bin Nusair and Tariq bin Ziyad arrived in

\footnotetext{
${ }_{5}^{5}$ Abdurrahman Ali al-Hajji Ali al-Hajji (1992), The Andalusian History, from the Islamic Conquest till the Fall of Granada $92-897$ A.H. (711-1492 C.E.), Damascus: Dar al-Qalam, p. 331.

${ }^{6}$ Ibid., p. 332.

${ }^{7}$ Meirison Meirison (2020), "Islamic Tolerance on Religious Freedom, Culture and Thought in Andalusia," HIKMATUNA: Journal for Integrative Islamic Studies, Vol. 6, No. 1, pp. 63-73.

${ }^{8}$ Manfred W. Wenner (1980), “The Arab/Muslim Presence in Medieval Central Europe," International Journal of Middle East Studies, Vol. 12, No. 1, pp. 59-79.

${ }^{9}$ U. A. Husin (n.d.), Kultur Islam, sedjarah perkembangan kebudajaan Islam dau pengaruhn ja dalam dunia internasional, publisher not identified, p. 114.

${ }^{10}$ Didier Ali Hamoneau (2013), L'histoire méconnue de l'islam en Gaule (VIIIe s.-Xe s.), Paris: La Ruche, p. 78.
} 
Andalusia in the year 91-94 Hijriyah (711M). Three years later, the military expedition reached the Northwestern part of the so-called Estuaries in the Galicia region to the Biscay Peninsula. The Muslim army could not completely control Aquitaine's area because the military led by Pelayo (737M), who had been defeated, was hiding in the Covadonga area. This area is called the European peak, consisting of the Cantabrian mountain range, which has three high peaks. The Pelayo Muslims named this area because they hid in this high mountain cave led by Don Pelayo in Covadonga. Muslims could not seize Pelayo and leave the area. This area grew the forerunner of the Spanish Reconquista power, which then grew to size slowly and managed to gradually control the Lion region and the Southwest region of the Iberian Peninsula. ${ }^{11}$ Fortresses surround this kingdom to protect its territory from Muslim attacks. ${ }^{12}$

Muslims have also occupied Gaul (now France), consisting of several provinces with Orbun as its capital. At the same time, the capital of the Aquitaine region is Bordeaux, positioned at the mouth of the river Gironde, Provence region in the North. This region was in the Northeastern part of Septimania, whose capital was Avignon. This region also adjoins the Rhone River's Rodna Valley, which is the Burgundy region west of the Rhone river. Samhah bin Malik also conducted military expeditions to German territory (100-102), which began by controlling Narbonne, Toulouse, and the Septimania region and swiftly establishing an Islamic government. He made the Narbonne region a military base for jihad, sited behind the Albert Mountains. Al-Samh bin Malik Khaulani continued to carry out military expeditions to the entire Aquitain Territory. Still, he was martyred in battle in the Toulouse region when the Muslims were defeated. The battle took many casualties in $107 \mathrm{H}$. The troops were brought home by Uzrah bin Abdullah al-Fihri who became the governor of the Southern French region in 110. The arrival of Muslims to French territory and the German border showed courage and strength of faith. The conquest of French territory was made by Anbasah and troops who had previously arrived in the Rhone region. Zuhair bin Qais, Hasan bin Nu'man Musa bin Nusair, members of the Uqbah Ibn Nafi 'al-Fihri army in Morocco, have played a role in the conquest of the Gaul region and the estuary of the Rhone river and the Aquitaine region. ${ }^{13}$

Anbasah's attack had alarmed European rulers, as Anbasah continued to expand from the Biscay Sea to Toulouse to Anjou (Italy) without resistance. However, France's kingdom, which Charles Martel and the Duke (dukes) joined in all parts of France, had united. He gathered contract soldiers from Germany and Russia and all the remaining Visigoths in the region to fight against the Muslims. They had occupied half of France and Italy. In just five years, 730-725 (107-102 H), it had been replaced by five judges because it was challenging to find wise rulers to control the political situation of a pluralistic society that came from Barbarians and indigenous people. They just converted to Islam and Arab leaders who came from Damascus with a dictatorial leadership style. ${ }^{14}$ The reins of leadership in Southern France shifted to Abdurrahman al-Ghafiqi. He was a wise figure who prioritized Muslims' benefit and had managed to control the political climate, especially among Muslim soldiers preparing to face the big war that would determine the future of Ummah, Italy, and Germany. Abdurrahman was appointed in 112 after Udzrah bin Abdullah al-Fihri, previously led by Anbasah, who died in a fierce battle against Duke Odo's army, Duke of Aquitain. Abdurrahman al-Ghafiqi organized his territorial administration in various provinces in Andalusia and Southern France for one year.

After the administration of the government was well-managed, he began to declare jihad against France. He gathered around 100,000 soldiers, both regular, contract (mercenary soldiers), and volunteer troops consisting of Barbarians, native Andalusians, and Arabs from Syria and Yemen. ${ }^{15}$ Abdurrahman and his soldiers moved north through the Pyrenia mountains towards the Aquitaine region. This area was the largest in Gaul or France at that time. Without putting up a fight, Abdurrahman Ad-Dakhil entered Bordeaux, the capital of Aquitain. He continued his expedition along the Loire river and controlled two cities at once, namely Poitiers and Tours. ${ }^{16}$ When the military mobilization reached Paris, Abdurrahman's troops were intercepted by Charles Martel's troops consisting of French, German and contract soldiers (mercenaries) from Russia.

\footnotetext{
${ }^{11}$ Wolfram Drews (2017), “Imperial Rule in Medieval Spain: Christian and Islamic Contexts,” The Medieval History Journal, Vol. 20, No. 2 , pp. 288-318.

${ }_{12}$ Abdul Halim Rajab Abdul Halim Rajab (2011), Alaqat Baina Andalus wa Isbania an-Nasraniyah, Kairo: Dar al-Hadits, p. 23.

${ }^{13}$ Sayid Abdul Aziz Abdul Aziz Salim (2016), Tarikh Muslimin Wa Atsaruhum Fi Al-Andalus, Kairo: Muasasah Syabab al-Jami'ah, p. 21.

${ }^{14}$ Ibid., p. 78.

${ }^{15}$ Hususayn Mu'nis (1996)), Mawsū'at Tārīkh Al-Andalus: Tārīkh, Wa-Fikr Wa-Haḍārah Wa-Turāth, al-Ṭab'ah 1, al-Qāhirah: Maktabat alThaqāah al-Dīnīyah, p. 55

${ }^{16}$ Ibid., p. 51.
} 
The two armies fought in Bilat's battle as-Syuhada (the stronghold of the martyrs) at the end of the month of Shaban $114 \mathrm{H} /$ October 732. The battle took place near Moussais la Bataille. Arab sources do not explain this place in detail due to the pain experienced in the battle, which claimed many casualties. Classical Arab historians are reluctant to recount the incident and try to forget it. The War of the Martyrdom lasted for eight fierce days in which both sides mobilized all their combat capabilities. The Muslims fought bravely until Charles Martel's army of Saxons, Burgundians, Germans, and Russian mercenaries overwhelmed them. The enemy attacked the Muslim forces from the front and back and took away the Muslim soldiers' spoils. The Muslim troops were in disarray, losing their fighting spirit, and Abdurrahman al-Ghafiqi tried to reunite ranks to resume the fight. However, it was unfortunate that the arrows pierced Abdurrahman's body, he was killed, and the troops were again in disarray. However, the fight continued into the night without anyone escaping the battle. That night, the Muslim troops returned to their headquarters in Septimania, leaving the spoils remains. Charles Martel and his troops found no one in the morning except for wounded soldiers and those who did not flee to Septimania. Charles Martel did not try to trace the Muslim soldiers who had fled because they had been preoccupied with the spoils that had been left. ${ }^{17}$

\section{Analysis of the Defeat of War Tours}

Al-Ghafiqi was very alert to potential internal conflicts and uprisings in Andalusia and possible threats from the North. Therefore, he immediately sent his troops north, across the Pyrenees, to fight against one of his governors in Southern France, Uthman ibn Abi Nis'ah, who opposed his leadership and aligned himself with the Christian rulers of the area, namely Odo, Duke of Aquitaine. The troops sent by al-Ghafiqi managed to crush Ibn Abi Nis'ah's resistance. Al-Ghafiqi himself then followed to the North with a strong army to face Duke Odo and his troops' threat. By comparing several historical sourcebooks both from the West and those compiled by the Arabs, the Authors analyzed the roots of Abdurrahman Al-Ghafiqi's defeat through various kinds of literature. ${ }^{18}$

Al-Ghafiqi entered French territory in the spring of 732 AD (early $114 \mathrm{AH}$ ), approximately one year after being appointed Guardian of Andalusia. One by one, his troops successfully occupied the Aquitaine area. Odo tried to hold al-Ghafiqi's troops on the banks of the Dordogne River. But in this battle, Odo suffered a crushing defeat, and many of his troops died in the war. All of Acquitaine then fell into Muslim hands. While Odo himself fled to the North, Muslim armies began to enter Burgundy's territory and conquered cities such as Lyon and Besancon. Some Muslim troops even managed to reach Sens, which is located only a hundred miles from Paris. Al-Ghafiqi's troops then moved westward to the banks of the Loire River. From this point, they prepared to head north towards the centre of the Frankish Empire (France). ${ }^{19}$ Charles Martel was aware that the barrier to conquering the south was Muslims who had occupied the southern region for nearly a decade, such as Toulouse, Provence, and most recently, Aquitaine. Al-Ghafiqi continued to sweep up the River Clain and Viene between the cities of Poitiers and Tours. Without realizing it, Charles Martel had sent spies to observe Arab and Barbarian Muslim soldiers' conditions. The Muslim soldiers crossed the river, showered with arrows, and finally retreated to the other side. There was a rain of arrows and skirmishes for several days. After that, there was a great, fierce battle that started from morning to night without a winner. At first, the victory had sided with the Muslim army, which numbered about 20,000 soldiers whose numbers had shrunk due to the war carried out in the Aquitaine region. On the other hand, Charles Martel had twice as large an army consisting of contract soldiers (mercenaries) from Germany, Belgium, Austria, Russia, and Poland. Charles Martel's army numbered 75,000. ${ }^{20}$

The two armies took up opposite positions. In several days the atmosphere was tense, silent, and scrutinizing like two great mountains. Each counted the opponent's strength and thought a thousand times to decide the opportune moment to attack. After several times, Abdurrahman Al-Ghafiqi saw that the Spirit of his troops was starting to burn. Such as their dependability and optimism about winning. So, he decided that the Islamic forces should attack first. Abdurrahman Al-Ghafiqi began to break through Western defences with his troops. The West was holding out like a strong fortress. The battle

\footnotetext{
${ }^{17}$ Taqqūsh, Tārīkh al-Muslimīn fì al-Andalus, p. 29.

18 Ibid., p. 56.

${ }^{19}$ Drews (2017), "Imperial Rule in Medieval Spain."

${ }^{20}$ Dr. Shawqi Abu Khalil Dr. Shawqi Abu Khalil (2014), Balat Al-Shuhada, Led by Abd Ar-Rahman Al-Ghafiqi, Damascus: Dar al-Fikr, pp. 29-30.
} 
raged for a whole day, and there was no sign of victory on either side. If they were not hindered by the darkness of the night, they would not have stopped fighting. As the second day began, the fighting erupted once more. The warriors of Islam attacked with courage and determination, but the West's defences had not been shaken. ${ }^{21}$

The war lasted for seven days in a row with a bang. On the eighth day, little by little, the enemy ranks began to tear apart. The hope of winning began to appear like a burst of dawn in the morning. But at the same time, a group of Western soldiers attacked the treasure trove of spoils and took almost all of it with ease. After seeing this, the Islamic forces began to waver. Most of them retreated to save the spoils from destroying the vanguard's defences. ${ }^{22}$ Commander-in-chief Abdurrahman al-Ghafiqi was persistent in preventing his soldiers from receding backwards while continuing to withstand the flow of attacks from the front and covering weak gaps. He moved swiftly in one place and another on his mighty horse. At this time, an arrow hit his body so that he fell from the horse and was martyred.$^{23}$ In the morning, Charles Martel found that the Islamic troops had left the Poitiers battlefield, but he did not dare to chase the Muslim troops. In fact, if he did, he would have succeeded in destroying the Muslims. He thought that the Islamic troops' retreat was intentional to lure them out of the open field. He thought it was a new Muslim strategy planned the night before. So Charles Martel decided to stay, and he felt the contentment for his ability to restrain the dangerous forces, then enjoyed the victory he achieved. ${ }^{24}$

The news of Al-Ghafiqi's death caused chaos in the Muslim army consisting of various ethnicities, Yemeni Arabs, Syrians, and Barbarian Muslims from North Africa. Previously, there had been ethnic strife in the community. After obtaining many spoils, Al-Ghafiqi was worried that this could disrupt his troops' concentration and morale, which continued to move towards the North, and he could not yet predict what would happen. The Tours war took place on October 10,732 AD. It was also called the Poitiers War, while Arab historians named the war Balath as-Syuhada. Abdurrahman's defeat was caused by the geographical structure where Muslim troops were not yet familiar with the field. When he was about to judge the betrayal of Usman bin Naisa al-Barbari, al-Ghafiqi might not have thought of making the duke Odo The Great, who had become Naisa al-Barbari's father-in-law as an ally in conquering all of the mainlands of Europe as was done by Sultan Usmani Bayazid I ( 1402 - 1413) with the rulers of Serbia so that all existing forces in Europe at that time could be conquered in the Kosovo war. ${ }^{25}$ Many of the members of Abdurrahman Al-Ghafiqi's army, which consisted of Barbarians, were disappointed that their leader was killed while fleeing from Muslim troops; this was the cause of their reduced loyalty to Abdurrahman Al-Ghafiqi. Another reason was that Abdurrahman did not have a cadre and never had a testament to lead the troops if he died or was killed in battle. Rasulullah has given instructions:

From 'Abdullah bin' Umar R.A., he said: Rasulullah SAW appointed Zaid bin Harithah as a leader in the battle of Mu'tah, then Rasulullah said, "If Zaid is killed, then (replaced) by Ja'far. And if Ja' far is killed, then (replaced) by 'Abdullah bin Rawahah". 'Abdullah (bin' Umar) said, "I was among them in that battle. We looked for Ja'far bin Abu Talib, then we found him among those who were killed, and I found that his body had more than ninety stab wounds and throws (arrows)". [H.R. Bukhari 5: 86] ${ }^{26}$

Despite the defeat in Tours' decisive war, the Muslims still occupied the Narbonne, Bordeaux, and Gaul regions for 20 years. Until Abdurrahman Ad-Dhakhil came and ordered the Muslim troops to retract from Gaul and made the territory only limited to Andalus in $756 \mathrm{AD} / 138 \mathrm{H}^{27}$

\section{Historical Evidence of Muslim Occupation}

The presence of Muslims in France, even Italy (Anjou), has taken place for a long time. At the peak of the power of the French Umayyads, they were part of the Islamic government in Andalusia. Muslim

\footnotetext{
${ }^{21}$ Mu'nis, Mawsū' at Tārīkh Al-Andalus, p. 76.

${ }^{22}$ Ibid., p. 330.

${ }^{23}$ Ali al-Hajji, The Andalusian History, p. 90

${ }^{24}$ Taqqūsh, Tārīkh Al-Muslimīn F̄̄ al-Andalus, p. 89.

${ }^{25}$ Emanuel Constantin Antoche (2017), "Hunyadi’s Campaign of 1448 and the Second Battle of Kosovo Polje (October 17-20)," in Norman Housley (ed.), Reconfiguring the Fifteenth-Century Crusade, London: Palgrave Macmillan, pp. 245-284.

${ }_{26}$ Muhạammad ibn Ismā'īl Bukhārī and Maḥmūd Muḥammad Maḥmūd Hasan Nașsār (2009), صحيح البخاري بيروت، لبنان: دار الكتب العلمية. p. p. 4301.

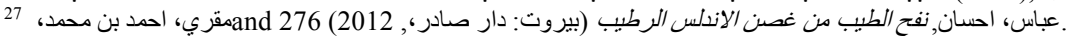


and non-Muslim scholars do not widely know this. Even the French ministry of education in history books taught in schools has deliberately missed this history. Islam has given a lot of colour to France's culture and lifestyles, such as cheese-making as introduced by Arab immigrants in the region of Gaul, whose capital is Bordeaux and many other areas. ${ }^{28}$

Meanwhile, Jewish and Christian history is studied comprehensively in French schools. This historical heresy has been going on for a long time to eliminate the scent of Islamic history in France, making many contributions to science in various fields. ${ }^{29}$ Muslims entered Europe not only as aggressors who then spread religion but also because they were invited by the local inhabitants who had been oppressed for a long time by the Visigoth rulers from time to time. When the Muslims entered France, there was not yet a country standing there, but a group of dukes fighting against each other, filled with cruelty and barbarity. They consisted of thieves and robbers, who some Christian priests protect for financial gain. France was known as the land of Gaul (La Gaule), which was entered by Muslims who spread security and lived with its inhabitants for a long time, starting in 714 AD. ${ }^{30}$ Muslims organized administration in several regions of France and Italy for approximately two and a half centuries beginning in 719-972 AD. ${ }^{31}$ During that time, there were riots and political instability, and replacement of governors. ${ }^{32}$ Muslims have been living in the Narbonne area for a long time in a fortress called Garde-Freinet, plus the Muslim community in Montpellier until the 12th century.

Cultural friction occurred in many Arabic sentences attached to French. Many people who lived in the south of France were of Arab and Barbarian descent. Musa bin Nusair carried out the first expansion of Muslims to France in 714-715. In 720, the Narbonne region led by as-Samh bin Malik al-Khaulani expanded to Toulouse (Italy). The commander was martyred in battle on June 9, 721 AD. ${ }^{33}$ Al-Samh bin Malik al-Khaulani was the governor of Andalusia appointed by Umar bin Abdul Aziz. Philippe Senac, a French historian, argues that the Narbonne region fell to the Islamic army in the middle of 719 $\mathrm{AD}$, to be precise in Zulhijah $100 \mathrm{H}$ in which Al-Samh bin Malik al-Khaulani led Muslim troops at that time. ${ }^{34}$

Among the evidence of the Muslim occupation in France is discovering several Islamic currencies in the Aquitaine region and the Narbonne region in southern France. This currency was minted in the 9th century A.D. ${ }^{35}$ In this currency, it is written Bislmillah ar-Rahman ar-Rahim la Ilaha Illa Allah wahdahu la Sharikalahu, and on the other part, there is the al-Ikhlas vein. In 1962, a ship bearing the Andalusian sign was found in the city of Cannes near the town of Agay, and in 1973 another ship was found on the coast of Cannes. In 1975, a Muslim heritage ship was found in the city of Marseille and Saint Tropez. ${ }^{36}$ The discovery of these ships in French territory indicated the intensive trade and communications activity in the 8th century A.D. occurred in the region.

Researchers have found a cemetery for Muslims in France. There were three large human skeletons buried in the city of Nimes (France). ${ }^{37}$ They were buried according to Islamic burial procedures, which were believed to have been buried since the 8th century A.D. The researchers used the Radioactive Carbon technique to perform DNA analysis of the skeleton. ${ }^{38}$ The research on DNA inherited by men's corpses explained that the skeleton was a soldier from North Africa during Islamic territory in Southern France. The research details have been elaborated in the Plos One Journal; it was found that three human skeletons were supported by their bodies on the right side and pointing to the Qibla, which indicated the corpses were Muslims. Two of the corpses were in their twenties, while the third was in their fifties. Radioactive Engineering explained that the bones dated back to the 7th or 8th century A.D. The gynaecologists commented that the bones of three corpses were scattered in North Africa and rarely found in Europe and France. The older skeleton was scattered in North Africa, while experts found the

\footnotetext{
${ }^{28}$ Tariq Salama Hasyim (2019), "Islamic Food In France” Culinary in France, Bordeaux: Al-Jazeera.

${ }^{29}$ Anan Muhammad Abdullah (1961), al-Atsar al-Andalusiah al-Baqiyah fi Isbaniyah wa Burtugal, Vol. 1, Kairo: Muasasah al-Khariji, p. 89.

${ }^{30}$ Abdul Halim Rajab, Alaqat Baina Andalus wa Isbania an-Nasraniyah, p. 90.

${ }^{31}$ Ahmad Mukhtar Ibadi Ahmad Mukhtar Ibadi (2017), Fi Tarikh al-Maghrib wa al-Andalus, Vol. 1, Kairo: Dar an-Nahdhah Misriyah, p. 88.

${ }^{32}$ Didier Ali Hamoneau (2013), L'histoire Méconnue de l'islam En Gaule (VIIIe s.-Xe s.), Paris: La Ruche.

${ }^{33}$ C. Grand (2016), Le Douloureux Passé de La Méditerranée: Histoire Books on Demand, p. 224

${ }^{34}$ Mohammed Arkoun (ed.) (2006), Histoire de l'islam et Des Musulmans En France Du Moyen Âge à Nos Jours, Paris: Albin Michel, pp. 164-166.

35 J. Duplessy (1956), La circulation des monnaies arabes en Europe occidentale du VIIIe au XIIIe siecle, Les belles lettres.

${ }^{36}$ Hamoneau, L'histoire Méconnue de l'islam En Gaule (VIIIe s.-Xe s.), p. 89.

${ }^{37}$ Yves Gleize et al. (2016), "Early Medieval Muslim Graves in France: First Archaeological, Anthropological and Palaeogenomic Evidence," PLOS ONE, Vol. 11, No. 2, pp. 1-13.

${ }^{38}$ Ibid.
} 
other two skeletons in Europe and North Africa. The research was also published at the University of Bordeaux in Plus One Journal entitled how did Muslim soldiers get to France at that time? ${ }^{39}$ Yves Gleize said, "the three soldiers came from the Umayyad Empire who conquered French territory, joining the local forces. The archaeological, anthropological, and gynaecological studies noted that the city of Nîmes was an Islamic territory in the 8th century A.D. The second oldest cemetery in France, dated from the 13th century A.D., was found in Marseille. ${ }^{40}$

Some historical evidence of the Muslim occupation of French territory and its influence is observable in the discovery of Islamic currency in the Aquitaine region and the Narbonne region. Both regions are in the Southern part of France. Archaeologists have examined the coin which was made in the 8th century A.D. ${ }^{41}$ Incisively, and this currency was printed in the year 95 Hijriyah (715-716 AD) during the time of the Umayyads. Alternatively, these areas were the Bani Umayah provinces located in Western Europe. ${ }^{42}$ The currency is read Allahu Ahad as-Samad Lam Yalid wa Lam Yulad wa Lam Yakun Lahu Kufuan Ahad. Several researchers also found ships with signs that indicated they came from Andalus. The ships were found in the area between Marseille and Cannes in 1962 near the city of Agay. Other ships were found in Cannes in 1973 A.D. The discovery resumed in 1975 where Muslim ships were floated near the city of Marseille. Following this, other ships were discovered in the Saint Tropez region. ${ }^{43}$ The huge number of Muslim ships found in these areas showed intensive trade and government activities. This specifies that Muslims had permanently built government structures and infrastructure in France.

In the field of architecture, the influence of Muslims in European countries and other western world exists until now. K.A.C Creswell announced one of his research discussed machicolation obtained from the art of Muslim architecture. ${ }^{44}$ This machicolation was formerly used for the defence and construction of fortresses. ${ }^{45}$ There were holes on its floors to shoot arrows and pour hot oil, hot water, and other weapons to attack the enemy. These castles are still adopted in Europe for relaxing in the morning and the afternoon. In the United States, this style of architecture is mostly built-in ordinary houses.

In general, Arabic literature depicts the political atmosphere of war and territory. Yet, Western literature emphasizes the evidence of the activities related to government administration, finance, trade, and science. The history that has not been studied previously in schools in France has emerged as the main interest of some scientists. The history of Islam in France is not discussed comprehensively as the history of the Jews. There is a continuing tendency to hide the works of Muslims, which are later claimed to be Western works.

\section{Conclusion}

Muslims in France have contributed to European civilization, which lost the Spirit of science long after the fall of the Roman Empire, which divided Rome into Eastern and Western Rome. Many Muslims have forgotten the Muslim occupation in France. Although it ended up in defeat in determining the future of Muslims in Western Europe, Muslims had been in the territory of France and Italy for 250 years, starting from 719 to $972 \mathrm{AD}$. The factors that caused the defeat of Abdurrahman Al-Ghafiqi were spoils that distracted the army's concentration and the execution of Usman bin Naisa 'Al Barbari, which was too early even though he betrayed. Rasulullah prohibited punishing criminals in a state of war. Still, it could be that pressure from the army had forced Abdurrahman to do so. Abdurrahman Al-Ghafiqi did not have a replacement cadre who should have been appointed before the war broke out. After Abdurrahman's death, parts of France were still in Muslims' hands, such as Toulouse and Provence. What is stated in the sources of Islamic history is not much different from the evidence by archaeologists, gynaecologists, and sociologists who claim that Islamic rule has been going on for a long time in France and the Italian region. Islamic currency has been used as a transaction tool in

\footnotetext{
${ }^{39}$ Ibid.

${ }^{40}$ Ibid.

${ }^{41}$ Duplessy, La circulation des monnaies arabes en Europe occidentale du VIIIe au XIIIe siecle.

${ }^{42}$ Meirison Meirison and Desmadi Saharuddin (2021), "The Distinction of Government Administration and Judicial Institutions in The Umayyad Dynasty," Buletin Al-Turas, Vol. 27, No. 1, pp. 123-138.

${ }^{43}$ Hamoneau, L'histoire méconnue de l'islam en Gaule (VIIIe s.-Xe s.).

${ }^{44}$ Marc Parvérie (2012), "D'Arbûnah à Sakhrat Abinyûn : quelques hypothèses sur la présence musulmane en Narbonnaise et dans la vallée du Rhône au vu des découvertes monétaires," Annales du Midi : revue archéologique, historique et philologique de la France méridionale. 124.278, p. 75 .

${ }^{45}$ Husin, Kultur Islam, p. 233.
} 
Bordeaux, whose inhabitants until now claim to have got the way of making cheese from Muslims who lived in Bordeaux hundreds of years ago. The historical evidence shows the existence of government and financial administration and trade activities and Western sources and scientific journals. In general, the Arabic literature describes more about expansion, governance, and power. Even though the western world tries to cover up the conquest of Muslims in France and Italy, there are still a few studies conducted by Western scientists themselves that have come to the fore.

\section{References}

Abdul Aziz Salim, Sayid Abdul Aziz (2016) Tarikh Muslimin wa Atsaruhum fi al-Andalus, Kairo: Muasasah Syabab al-Jami'ah.

Abdul Halim Rajab, Abdul Halim Rajab (2011), Alaqat Baina Andalus wa Isbania an-Nasraniyah, Kairo: Dar al-Hadits.

Ahmad Mukhtar Ibadi, Ahmad Mukhtar Ibadi (2017), Fi Tarikh al-Maghrib wa al-Andalus, Vol. 1, Kairo: Dar an-Nahdhah Misriyah.

Ali al-Hajji, Abdurrahman Ali al-Hajji (1992), The Andalusian History, from the Islamic conquest till the fall of Granada 92-897 A.H. (711-1492 C.E.), $2^{\text {nd }}$ Edition, Damascus: Dar al-Qalam.

Antoche, Emanuel Constantin (2017), "Hunyadi's Campaign of 1448 and the Second Battle of Kosovo Polje (October 17-20)," in Norman Housley (ed.), Reconfiguring the Fifteenth-Century Crusade, 245284, London: Palgrave Macmillan.

Arkoun, Mohammed (ed.) (2006), Histoire de l'islam et des musulmans en France du Moyen Âge à nos jours, Paris: Albin Michel.

Bukhārī, Muḥammad ibn Ismā‘̄îl, and Maḥmūd Muḥammad Maḥmūd Ḥasan Nașṣār (2009), صحيح البخاري, بيروت، لبنان: دار الكتب العلمية.

Drews, Wolfram (2017), "Imperial Rule in Medieval Spain: Christian and Islamic Contexts," The Medieval History Journal, Vol. 20, No. 2, 288-318.

Duplessy, J. (1956), La circulation des monnaies arabes en Europe occidentale du VIIIe au XIIIe siecle, Les belles lettres.

Gleize, Yves et al. (2016), "Early Medieval Muslim Graves in France: First Archaeological, Anthropological, and Palaeogenomic Evidence," Plos One, Vol. 11, No. 2, 1-13.

Grand, C. (2016), Le douloureux passé de la Méditerranée: Histoire, Books on Demand.

Hamoneau, Didier Ali (2013), L'histoire méconnue de l’islam en Gaule (VIIIe s.-Xe s.), Paris: La Ruche.

Hasyim, Tariq Salama (21 October 2019), "Islamic Food In France," in Culinary in France, Bordeaux: Al-Jazeera.

Husin, U. A. (n.d.), Kultur Islam, sedjarah perkembangan kebudajaan Islam dau pengaruhn ja dalam dunia internasional, oleh Oemar Amin Hoesin, n.p.

Meirison, Meirison (2020), "Islamic Tolerance on Religious Freedom, Culture and Thought in Andalusia," Hikmatuna Journal for Integrative Islamic Studies, Vol. 6, No. 1, 63-73.

Meirison, Meirison and Saharuddin, Desmadi (2021), "The Distinction of Government Administration and Judicial Institutions in The Umayyad Dynasty," Buletin Al-Turas, Vol. 27, No. 1, 123-138.

Muhammad Abdullah, Anan (1961), al-Atsar al-Andalusiah al-Baqiyah fi Isbaniyah wa Burtugal, Vol. 1, Kairo: Muasasah al-Khariji. 
Mu'nis, Husayn (1996), Mawsū'at tārīkh al-Andalus: tārīkh, wa-fikr wa-hadārah wa-turāth, alQāhirah: Maktabat al-Thaqāfah al-Dīnīyah.

Parvérie, Marc (2012), “D’Arbûnah à Sakhrat Abinyûn: quelques hypothèses sur la présence musulmane en Narbonnaise et dans la vallée du Rhône au vu des découvertes monétaires," Annales du Midi : revue archéologique, historique et philologique de la France méridionale, 165-181.

Shawqi Abu Khalil (2014), Balat Al-Shuhada, Led by Abd Ar-Rahman Al-Ghafiqi, Damascus: Dar alFikr.

Ṭaqūsh, Muḥammad Suhayl (2005), Tārīkh al-Muslimīn fì al-Andalus, 91-897 H/710-1492 M, AlṬab'ah 1, Bayrūt: Dār al-Nafā'is.

Wandiyo Wandiyo, Ida Suryani and Kabib Sholeh (2020), "Hubungan Sriwijaya dengan Dinasti Umayah terhadap Masuknya Agama Islam di Palembang pada Abad VIII Masehi," Sindang: Jurnal Pendidikan Sejarah dan Kajian Sejarah, Vol. 2, No. 1, 32-43.

Wenner, Manfred W. (1980), "The Arab/Muslim Presence in Medieval Central Europe," International Journal of Middle East Studies, Vol. 12, No. 1, 59-79.

$$
\begin{aligned}
& \text { محمد،, ابن عذاري، البيان الدغرب في أخبار الأندلس والدغرب , Vol. 4., al. (2009), دار الكتب العلمية. } \\
& \text { بيروت: دار صادر, نفح الطيب من غصن الاندلس الرطيب (2012) مقري، احمد بن محمد dna عباس، احسان. }
\end{aligned}
$$


Journal of Al-Tamaddun, Vol. 16 (1), 2021, 17-25 